\title{
Im eller in dem? Et forsøg på en skalar forklaring'
}

\author{
MADS CHRISTIANSEN
}

Institut for Sprog, Litteratur og Kultur, Sektion for Tysk, Aarhus Universitet, Danmark

\begin{abstract}
Das Thema dieser Arbeit ist die Verschmelzung von Präposition und bestimmtem Artikel im Deutschen. Vor dem Hintergrund der These, die Wahl zwischen der Verschmelzung und der analytischen Präposition-ArtikelVerbindung sei von den unterschiedlichen Referenzeigenschaften der beiden Möglichkeiten abhängig, soll untersucht werden, ob sich der Gebrauch von im und in dem anhand eines skalaren Beschreibungsmodells erklären lässt. Grundlegend wird davon ausgegangen, dass die analytische Präposition-Artikel-Verbindung eine eindeutigere Referenz ausdrückt als die Verschmelzung.
\end{abstract}

Den Ausgangspunkt des skalaren Beschreibungsmodells bilden Hartmanns Behandlung von generischer und spezifischer Interpretation des bestimmten Artikels (Hartmann 1978) und seine Behandlung von phorischer Kraft (Hartmann 1980). Es soll der Versuch unternommen werden, den spezifischen Anwendungsbereich, der ein besonderes Problem darstellt, in Unterkategorien aufzuteilen, die den Gebrauch der beiden Möglichkeiten beschreiben.

Dies geschieht anhand des Begriffs "Spezifikationsgrad", worunter der Grad der "Referenzeindeutigkeit" einer Verschmelzung bzw. einer analytischen PräpositionArtikel-Verbindung verstanden wird. Der Spezifikationsgrad lässt sich anhand so genannter "Spezifikationsfaktoren" festlegen. Abhängig von der Art und der Kombination der Spezifikationsfaktoren wird zwischen niedrigstem, mittlerem und höchstem Spezifikationsgrad unterschieden.

In den zum niedrigsten Spezifikationsgrad gehörenden Beispielen erweist sich die Verschmelzung, in den zum höchsten Spezifikationsgrad gehörenden Beispielen die analytische Präposition-Artikel-Verbindung als obligatorisch, während im mittleren Spezifikationsgrad eine Variationsmöglichkeit besteht.

Tidsskrift for Sprogforskning, årgang 6, 2008

Århus: Statsbiblioteket

Artikel nr. 2, Christiansen, Mads, 28 pp.

http://ojs.statsbiblioteket.dk/index.php/tfs/index 


\section{MADS CHRISTIANSEN}

\section{INDLEDNING}

Nogle præpositioner og nogle former af den bestemte artikel i tysk danner undertiden en sammensmeltningsform (ssf.), fx im. Det faktum, at der til tider i stedet for ssf. optræder en analytisk præposition-artikel-forbindelse (apaf.), fx in dem, foranlediger spørgsmålet om, hvilken bagvedliggende systematik der afgør valget mellem de to muligheder.

Søger man et svar på dette spørgsmål i grammatikhåndbøgerne, konstateres en tendens til at lade opstilling af regler byggende på en bagvedliggende systematik træde i baggrunden til fordel for forklaring af enkeltstående eksempeltyper. Således kan man i Duden 4 (1998: 324) fx læse, at ssf. er obligatorisk ved am + superlativ. En regel, der næppe bringer læseren tættere på en forståelse af systematikken bag fænomenet. ${ }^{2}$ Grammatikhåndbøgernes tøven med at opstille regler byggende på en bagvedliggende systematik er for så vidt forståelig, som den må formodes at grunde i, at fænomenet ikke er helt regelstyret. Således er der heller ikke $\mathrm{i}$ forskningen til emnet blevet opstillet en fuldstændig beskrivelsesmodel.

På baggrund af beskæftigelse med et større eksempelmateriale fra Mannheimer Korpus 1 har jeg opstillet den tese, at forskellen i brug af ssf. og apaf. grunder i, at disse ikke besidder samme referenceegenskaber. Således antages det grundlæggende, at apaf. udtrykker en mere entydig reference end ssf. Hvis denne tese er korrekt, må det være muligt at forklare forskellen i brug af ssf. og apaf. ud fra en skalar beskrivelsesmodel. Herved forstås en model, på hvis respektive trin ssf. og apaf. lader sig indordne på baggrund af deres referenceentydighed. I denne artikel vil jeg således forsøge at opstille, afprøve og vurdere anvendeligheden af en skalar beskrivelsesmodel.

Da en skalar beskrivelsesmodel mig bekendt ikke tidligere i forskningen til emnet er forsøgt opstillet ${ }^{3}$, må den i nogen grad bygge på et begrebsapparat, jeg selv opstiller. Det centrale begreb i min undersøgelse, der skal bruges til at fastlægge graden af referenceentydighed $i$ en given ssf. eller apaf., betegner jeg specifikationsgrad.

Opstillingen af en skalar beskrivelsesmodel kan med fordel tage udgangspunkt i en korrelation af behandlingen af generisk og specifik anvendelse af den 
bestemte artikel hos Hartmann (1978) og behandlingen af forisk kraft hos Hartmann (1980).

Efter opstilling af en skalar beskrivelsesmodel skal denne appliceres på et empirisk materiale. Dette består af de første 100 eksempler med henholdsvis im og in dem i Mannheimer Korpus 1. Et udvalg af eksempler vil blive kommenteret, ligesom det formålstjenlige i dette valg af empirisk materiale vil fremgå.

Er min tese korrekt, kan den skalare beskrivelsesmodel i idealtilfældet forklare systematikken i brug af ssf. og apaf., hvilket kunne give anledning til en revurdering af grammatikhåndbøgernes fremstilling af emnet med henblik på opstilling af mere systematiske regler. Dette ville - især i fremmedsprogsundervisningen - være hensigtsmæssigt.

Som baggrund for opstilling af en skalar beskrivelsesmodel bringes i det følgende kapitel et overblik over forskningens behandling af emnet.

\section{BAGGRUND FOR OPSTILLING AF SKALAR BESKRIVELSESMODEL}

\subsection{Overblik over den nyere forsknings behandling af emnet}

Siden slutningen af 1970'erne ${ }^{4}$ er emnet blevet behandlet særligt med henblik på tre aspekter:

\section{Det fonetiske aspekt}

Det funktionelle ${ }^{5}$ aspekt

Grammatikaliseringsaspektet

De respektive fremstillinger retter i reglen fokus mod ét af de tre aspekter, men da en separat behandling ikke er uproblematisk, inddrages i et vist omfang ofte alle tre aspekter.

I denne artikel skal imidlertid udelukkende anlægges et funktionelt perspektiv. Den følgende behandling af forskningslitteraturen falder på baggrund heraf i to afsnit: Først skal der argumenteres for, at en udelukkelse af det fonetiske aspekt og grammatikaliseringsaspektet ved bevidst valg af empirisk materiale er mulig. Dernæst behandles forskningslitteraturen til det funktionelle aspekt med særligt 


\section{MADS CHRISTIANSEN}

henblik på en vurdering af de teorier og begreber, i hvilke opstillingen af en skalar beskrivelsesmodel skal tage udgangspunkt.

\subsection{Fonetik ${ }^{6}$ og grammatikalisering - determinerende faktorer?}

Forudsætningen for på metodisk forsvarlig vis at kunne se bort fra disse to aspekter er, at de ikke er at betragte som determinerende faktorer for valget mellem ssf. og apaf. Til belysning af dette problem behandles i dette afsnit Nübling (2005), der særligt behandler grammatikaliseringsaspektet, og Schmöe (2004), der behandler emnet bredt, men på hvis behandling af det fonetiske aspekt jeg her skal fokusere.

Nübling $(2005: 108,112)$ skelner ud fra grammatikaliseringsgrad mellem to slags klitika, hvilket i denne sammenhæng vil sige ssf. De seks mest grammatikaliserede ssf., im, am, zum, beim, vom, zur, betegnes specielle klitika, mens alle øvrige ssf. betegnes enkle klitika. ${ }^{7}$ Et specielt klitikon kan ikke udskiftes med apaf., uden at dette enten medfører ugrammatiske udtryk eller en betydningsændring. Denne udskiftning er imidlertid uden betydningsændring mulig ved de enkle klitika. Betydningen af dette vender jeg tilbage til.

Nübling (2005) forklarer ikke, hvad der ligger til grund for de specielle klitikas høje grammatikaliseringsgrad. Ved inddragelse af behandlingen hos Schmöe (2004) af, hvilke fonetiske egenskaber der konstituerer en "god" ${ }^{8}$ ssf., ses imidlertid, at der synes at være et sammenfald mellem "gode" ssf. og specielle klitika. Schmöe (2004: 212f) opfører tre fonetisk begrundede kriterier for en "god" ssf.: Enstavelsespræpositioner egner sig bedst til ssf., maskulinums- og neutrumsformer af den bestemte artikel indgår snarere end femininumsformer $\mathrm{i}$ ssf., og dativformer af den bestemte artikel foretrækkes frem for akkusativformer. Ved nærmere eftersyn opfylder de seks mest grammatikaliserede ssf. disse kriterier, idet zur dog ikke opfylder det andet kriterium.

Det ovenfor beskrevne har betydning for mit valg af empirisk materiale, der som nævnt består af eksempler med im og in dem. Da im er et specielt klitikon - og således opfylder de tre kriterier hos Schmöe (2004) - må man formode, at det ikke er det fonetiske aspekt og grammatikaliseringsaspektet, der er determinerende for valget mellem im og in dem, idet specielle klitika ikke uden betydningsændring kan udskiftes med apaf. 
Således antages, at en forudsætning for at nærme sig en forståelse af en bagvedliggende systematik må være en bevidst afgrænsning af det empiriske materiale, idet fokus dermed kan rettes udelukkende mod det funktionelle aspekt.

\subsection{Det funktionelle aspekt}

I den følgende behandling af forskningslitteraturen til det funktionelle aspekt fokuseres primært på Hartmann (1978) og Hartmann (1980). Til grund herfor ligger den betragtning, at en korrelation af de i disse to artikler fremsatte synspunkter - der, hvis man skal tro Hartmann (1980: 179), er kontrære danner udgangspunktet for opstilling af en skalar beskrivelsesmodel. Dette skal jeg argumentere for i det følgende.

At tage udgangspunkt $\mathrm{i}$ nogle af de ældste artikler om emnet anser jeg ingenlunde for problematisk, idet Hartmanns behandling danner det teoretiske og begrebsmæssige udgangspunkt for størstedelen af de senere behandlinger af emnet under funktionelt perspektiv, eksempelvis for Haberland (1985), Raffelsiefen (1987) og Schellinger (1988). Den nyere forskning til emnet skal kun inddrages i den relevante sammenhæng, det vil primært sige de steder i analysedelen, hvor den vurderes at kunne bidrage til belysning af diverse problemstillinger, men i øvrigt ikke som Hartmann (1978) og Hartmann (1980) gøres til genstand for en mere systematisk gennemgang.

Hartmann (1978) undersøger sammenhængen mellem generisk og specifik anvendelse af den bestemte artikel, i det følgende samlet kaldt artikelsemantik, og brugen af ssf./apaf. Ved generisk anvendelse forstår han det, at den bestemte artikel henviser til en hel klasse af objekter, og ikke, som i specifik anvendelse, til ét bestemt objekt (Hartmann 1978: 71f). Følgende eksempel ${ }^{9}$ kan illustrere denne distinktion:

\section{(1) Der Hund bellt}

'Hunden gør'

Eksemplet rummer mulighed for både generisk og specifik interpretation. Således kan det dels betyde, at det er et karakteristikum for hunderacen som sådan at gø (generisk), dels at en bestemt hund gør (specifik). ${ }^{10}$ Mht. sammenhængen 


\section{MADS CHRISTIANSEN}

mellem artikelsemantik og brugen af ssf./apaf. drager Hartmann (1978: 79) den konklusion, at mens generisk anvendelse kun tillader ssf., så tillader specifik anvendelse både ssf. og apaf.

Hartmann (1980: 179f) afviser på baggrund af det specifikke anvendelsesområdes dobbelte paradigme artikelsemantikken som determinerende faktor. Den bagvedliggende systematik består i stedet i, at der i anaforisk, dvs. tilbagevisende, og i deiktisk, dvs. henvisende, anvendelse vælges apaf., i ikke-anaforisk og ikkedeiktisk anvendelse ssf.

Når Hartmann (1980) afviser artikelsemantikken som determinerende faktor, er det for så vidt forståeligt, som han ikke opererer med en underopdeling af det specifikke anvendelsesområde. Uden en sådan siger artikelsemantikken intet praktisk brugbart om valget mellem ssf. og apaf., ud over at ssf. er obligatorisk i generisk anvendelse. Den senere forskning har dog vist, at heller ikke spørgsmålet om anaforisk og deiktisk kraft alene kan forklare brugen af ssf. og apaf. ${ }^{11}$

Jeg skal argumentere for, at man med henblik på opstilling af en skalar beskrivelsesmodel byggende på referenceegenskaber - det ovenfor nævnte til trods - kan tage udgangspunkt i Hartmann (1978) og Hartmann (1980). Betragter man Hartmanns definition dels af generisk og specifik anvendelse af den bestemte artikel, dels af anaforisk og deiktisk kraft, ser man, at disse begge bygger på spørgsmålet om henvisning, altså på spørgsmålet om reference. Denne affinitet er vigtig, idet den, som jeg skal vise, åbner muligheden for en korrelation af artikelsemantik og forisk kraft. En sådan korrelation er naturligvis kun hensigtsmæssig, hvis man på baggrund heraf kan beskrive det specifikke anvendelsesområdes dobbelte paradigme, dvs. kan opdele det i underkategorier, der siger noget om valget mellem ssf. og apaf. Dette anser jeg for muligt, idet jeg skal argumentere for, at valget mellem ssf. og apaf. står i et mere komplekst forhold til spørgsmålet om forisk kraft end antaget hos Hartmann (1980). Således holder jeg i min opstilling af en skalar beskrivelsesmodel fast i den grundlæggende distinktion mellem generisk og specifik anvendelse af den bestemte artikel, men vil argumentere for, at det specifikke anvendelsesområde lader sig inddele i underkategorier bl.a. på baggrund af en differentiering mellem de forskellige typer af forisk kraft. 
Begrebet forisk kraft omfatter tre underbegreber: anaforisk og deiktisk kraft, der allerede er blevet omtalt, samt kataforisk kraft, som Hartmann (1980) imidlertid ikke gør meget ud af. Et eksempel ${ }^{12}$ herpå er:

(2) Das hatte Peter sich nicht träumen lassen, dass er noch einmal am Nordpol stehen würde

'Det havde Peter ikke drømt om, at han endnu engang skulle stå på Nordpolen'

Das viser i dette eksempel frem til den efterfølgende dass-sætning, der uddyber indholdet af das. Som vi skal se, indgår kataforisk kraft i den skalare beskrivelsesmodel på linje med den foriske krafts to andre underbegreber.

Anaforisk kraft defineres af Hartmann (1980: 176) som det, at et givet objekt lader sig identificere, idet det allerede tidligere i teksten er blevet nævnt. Følgende eksempel ${ }^{13}$ illustrerer dette:

(3) Ein Vogel flog auf den Balkon. Fritz fütterte den Vogel mit Begeisterung 'En fugl fløj op på altanen. Fritz fodrede fuglen med begejstring'

Eksemplet er uproblematisk, da der næppe kan herske tvivl om, at der med den Vogel vises tilbage til den fugl, der just er blevet indført i diskursen som ein Vogel. Hartmann (1980: 176) lader imidlertid også begrebet omfatte tilfælde, hvor fx "Gras" viser tilbage til "Rasen", altså ikke blot eksempler, hvor det samme ord gentages. ${ }^{14}$ Apaf. er, som tidligere nævnt, ifølge Hartmann (1980: 179f) obligatorisk i eksempler med anaforisk kraft.

Mens jeg anser definitionen af anaforisk kraft hos Hartmann (1980) for hensigtsmæssig, stiller jeg mig mere kritisk over for hans definition af deiktisk kraft. Hartmann (1980: 176) definerer deiktisk kraft som henvisning uden anaforisk eller kataforisk kraft til et objekt, der er til stede i en talendes og en tilhørers fælles iagttagelsesrum. Et eksempel herpå er:

(4) Paß auf die Stufe auf!

'Pas på trinnet' 


\section{MADS CHRISTIANSEN}

Således foreligger der i dette eksempel deiktisk kraft, idet Stufe lader sig identificere som en del af kommunikanternes fælles iagttagelsesrum. Apaf. er, som tidligere nævnt, ifølge Hartmann (1980: 179f) obligatorisk i eksempler med deiktisk kraft.

Haberland (1985: 89) har imidlertid gjort opmærksom på, at også ssf. undertiden synes omfattet af denne definition. På denne baggrund konkluderer Schmöe (2004: 218), at ssf. afhængig af kommunikationssituationen kan have deiktisk kraft. Desværre er det uklart, hvad der præcist skal forstås ved kommunikationssituation.

Dette illustrerer ganske godt de definitoriske vanskeligheder, der er forbundet med begrebet deiktisk kraft. Jeg skal senere - foranlediget af disse definitoriske vanskeligheder - gøre mig nogle definitoriske overvejelser mht. dette begreb og dets anvendelighed i forbindelse med det i denne artikel behandlede emne. Disse definitoriske overvejelser skal endvidere ses som et led i mit forsøg på at forklare brugen af ssf. og apaf. i det specifikke anvendelsesområde ud fra bl.a. typen af forisk kraft.

\section{OPSTILLING AF SKALAR BESKRIVELSESMODEL}

\subsection{Specifikationsgrad - den skalare beskrivelsesmodels centrale begreb}

Med udgangspunkt i den $i$ forrige kapitel påviste affinitet mellem artikelsemantik og forisk kraft skal i dette afsnit opstilles en skalar beskrivelsesmodel. Det understreges, at der ved skalar som udgangspunkt forstås fastafgrænsede trin og ikke et kontinuum med glidende overgange mellem de forskellige trin, da dette af hensyn til beskrivelsesmodellens praktiske anvendelighed anses for mest hensigtsmæssigt. Samtidig skal det dog pointeres, at dette ikke udgør nogen hindring for overvejelser om anvendeligheden af en model med glidende overgange mellem de forskellige trin, hvis dette viser sig formålstjenligt.

Det er evident, at anvendeligheden af en skalar beskrivelsesmodel først og fremmest afhænger af dens evne til at beskrive det specifikke anvendelsesområdes dobbelte paradigme. Da valget mellem ssf. og apaf. som tidligere nævnt antages at være reguleret af disses forskellige referenceegenskaber, idet apaf. udtrykker en mere entydig reference end ssf., 
indfører jeg begrebet specifikationsgrad. Dette defineres som graden af referenceentydighed i en given ssf. eller apaf. Ud fra specifikationsgraden skal det specifikke anvendelsesområde forsøges inddelt i underkategorier til beskrivelse af valget mellem ssf. og apaf.

På baggrund af min forståelse af skalar er det vigtigt, at specifikationsgraden lader sig fastlægge ud fra klare kriterier. Jeg indfører til dette formål begrebet specifikationsfaktor. Herved forstås elementer af forskellig karakter, under hvis tilstedeværelse referenceentydigheden i en given ssf. eller apaf. stiger. Jeg opererer med to specifikationsfaktorer: forisk kraft og attributter, der dækker over flere underbegreber. At disse specifikationsfaktorer bidrager til en større referenceentydighed, skal med udgangspunkt i det empiriske materiale demonstreres i næste kapitel. I dette kapitel skal blot kort skitseres, hvilke grundlæggende overvejelser der ligger bag antagelsen om referenceentydighedens målbarhed.

Som tidligere nævnt skal jeg argumentere for, at forisk kraft med dens tre underbegreber står i et mere komplekst forhold til valget mellem ssf. og apaf. end antaget hos Hartmann (1980), nærmere bestemt, at de tre typer af forisk kraft fordeler sig på hver sin specifikationsgrad, altså hver sin underkategori i det specifikke anvendelsesområde, da de ikke er forbundet med samme grad af referenceentydighed. Sammenligner man (3) og (4), eksempler på henholdsvis anaforisk og deiktisk kraft, kan dette demonstreres. Mens der i (3) henvises til en konkret størrelse i den tekstuelle overflade, Vogel, er dette ikke tilfældet i (4), hvor Stufe i højere grad er tekstinternt identificerbar, altså primært identificerbar for kommunikanterne. Som følge deraf kan (4) siges ikke at besidde samme referenceentydighed som (3), hvor identificerbarheden også teksteksternt er mulig. ${ }^{15}$

Også attributter betragtes som en specifikationsfaktor, da det synes plausibelt, at disse bidrager til en højere specifikationsgrad. Følgende eksempel ${ }^{16}$ turde underbygge denne påstand:

\section{Dort fährt ein rotes Auto}

'Dér kører en rød bil' 


\section{MADS CHRISTIANSEN}

Det attributive adjektiv rotes kan siges at have en semantisk specificerende karakter, idet det afgrænser den omtalte bil fra alle biler, der ikke er røde. Ved siden af adjektivisk attribut opereres i det følgende med præpositionelt og genitivisk attribut.

Det skal endvidere afklares, hvorledes specifikationsgraden med udgangspunkt i specifikationsfaktorerne fastlægges. Jeg går ud fra tre specifikationsgrader, som jeg betegner som laveste, mellemste og højeste specifikationsgrad. Højeste specifikationsgrad defineres som eksempler med tilstedeværelse af mindst to specifikationsfaktorer eller kataforisk kraft, mellemste specifikationsgrad som eksempler med tilstedeværelse af én specifikationsfaktor (attribut eller anaforisk kraft) og laveste specifikationsgrad som eksempler med tilstedeværelse af deiktisk kraft.

Disse tre specifikationsgrader omfatter tilsammen hele det specifikke anvendelsesområde, idet det antages, at mens ssf. er obligatorisk i laveste specifikationsgrad, apaf. obligatorisk i højeste specifikationsgrad, så er mellemste specifikationsgrad en slags overgangsområde med begge muligheder. Logikken i disse definitioner og inddelinger skal i løbet af analysen afprøves, forklares og vurderes nærmere. Følgende oversigt, der er en forenklet udgave af skema i bilaget, illustrerer den følgende analyse:

\begin{tabular}{|c|c|c|c|c|}
\hline $\begin{array}{l}\text { Generisk } \\
\text { anvendelse }\end{array}$ & \multicolumn{4}{|c|}{ Specifik anvendelse } \\
\hline \multirow{3}{*}{ Diverse typer } & \multirow{3}{*}{$\begin{array}{l}\text { Laveste } \\
\text { spec.grad }\end{array}$} & \multicolumn{2}{|c|}{ Mellemste specifikationsgrad } & \multirow{2}{*}{$\begin{array}{l}\text { Højeste } \\
\text { spec.grad }\end{array}$} \\
\hline & & Attribut & Anaforisk kraft & \\
\hline & & Diverse typer & & Diverse typer \\
\hline \multicolumn{2}{|c|}{ Ssf. obligatorisk } & \multicolumn{2}{|c|}{ Variationsmulighed ssf./apaf. } & $\begin{array}{c}\text { Apaf. } \\
\text { obligatorisk }\end{array}$ \\
\hline
\end{tabular}

Før end den skalare beskrivelsesmodel skal afprøves i praksis, skal i det følgende afsnit gøres nogle bemærkninger til det empiriske materiale. 


\subsection{Det empiriske materiale}

Den skalare beskrivelsesmodel skal i næste kapitel appliceres på et empirisk materiale. Dette består som tidligere nævnt af de første 100 eksempler med henholdsvis im og in dem i Mannheimer Korpus 1, af hvilke et for de forskellige eksempeltyper repræsentativt udvalg skal kommenteres. Jeg har tidligere argumenteret for det formålstjenlige i dette valg af empirisk materiale.

Det kræver en betydeligt større tekstmængde at indsamle 100 eksempler med in dem end med im. Mens mine 100 eksempler med im kunne indsamles på små 30.000 ord, krævede det små 500.000 ord at indsamle 100 eksempler med in dem. Det fornuftige i ikke at begrænse indsamlingen af eksempelmateriale til en bestemt tekstmængde turde således fremgå. Dette ville medføre en overrepræsentation af eksempler med im, hvilket i denne sammenhæng, hvor en sammenligning mellem brugen af de to muligheder står i centrum, ville være uhensigtsmæssigt.

Bilaget viser den skalare beskrivelsesmodel, idet de bragte eksempler er angivet med deres respektive sigel og efterfølgende sidehenvisning, således at de kan findes i Mannheimer Korpus 1. Endvidere er i bilaget angivet frekvensen af ssf./apaf. i de respektive underkategorier.

Det empiriske materiale behandles i næste kapitel først med udgangspunkt i det generiske, dernæst med udgangspunkt i det specifikke anvendelsesområde, idet fokus primært rettes mod det specifikke anvendelsesområde.

\section{DEN SKALARE BESKRIVELSESMODEL I PRAKSIS}

\subsection{Det generiske anvendelsesområde}

Da brugen af ssf. i generisk anvendelse er obligatorisk, er behandlingen heraf ikke et lige så vigtigt led i min analyse som behandlingen af det specifikke anvendelsesområde. Dog skal oprettelsen af to underkategorier, som det empiriske materiale her danner grundlag for at oprette, gennemføres for fuldstændighedens skyld. Jeg betegner disse to underkategorier henholdsvis generisk anvendelse I og generisk anvendelse II. De behandles i nævnte rækkefølge.

Eksempler på generisk anvendelse I: 


\section{MADS CHRISTIANSEN}

(6) $[u]$ nd doch ist diese Wohnung, in der ich nur drei bis vier Wochen im Jahr verbringe, mir fremder als [...]

'og dog er denne lejlighed, som jeg kun tilbringer tre til fire uger i om året, mere fremmed for mig end'

(7) [d]enn es war keiner anwesend [...], der nicht mindestens seine fünfzehnhundert Mark im Monat verdiente

'for der var ingen til stede, som ikke tjente mindst femten hundrede mark om måneden'

Karakteristisk for eksemplerne i generisk anvendelse I er, at de semantisk nærmer sig faste ordforbindelser, der - som det vil fremgå af afsnit 4.3. - ikke skal forsøges indplaceret i den skalare beskrivelsesmodel. Det understreges dog, at der i forskningen synes at herske konsensus om at regne eksempler som (6) og (7) for generiske og ikke for faste ordforbindelser. ${ }^{17}$ Det kan diskuteres, om det empiriske materiale overhovedet danner grundlag for oprettelse af denne underkategori, idet der ud over (6) udelukkende forekommer eksempler som (7), dvs. med im Monat. Når den oprettes, skyldes det den åbenlyse forskel til generisk anvendelse II, der ses ved sammenligning med følgende eksempler herpå:

[d] a ich diese Nummer meistens im Zug noch einmal durchgehe [...]

'da jeg for det meste gennemgår dette nummer i toget endnu engang'

(9) [a]ber sobald Fredebeul im Zimmer ist, braucht kein Gastgeber Angst vor einer Gesprächspause zu haben

'men så snart Fredebeul er $\underline{\text { i stuen, }}$ behøver ingen vært at frygte en pause i samtalen'

Eksemplerne illustrerer, at mens man i generisk anvendelse I umiddelbart ved læsning af den respektive ssf. kan afgøre, at der foreligger generisk anvendelse, er dette i generisk anvendelse II i reglen først muligt under inddragelse af konteksten. Således kan man i (8) og (9) først ud fra konteksten afgøre, at der ikke refereres til et bestemt tog (8) eller en bestemt stue eller værelse (9). Generisk anvendelse II må på denne baggrund betegnes som mere integreret $\mathrm{i}$ den skalare beskrivelsesmodel end generisk anvendelse I, idet spørgsmålet om referenceegenskaber, som den skalare beskrivelsesmodel grundlæggende bygger 
på, her er mere aktuelt end i generisk anvendelse I. Dette fremgår også af, at det undertiden kan være vanskeligt at afgøre, om der foreligger generisk anvendelse II eller specifik anvendelse af laveste specifikationsgrad.

Generelt må det generiske anvendelsesområde betegnes som uproblematisk. Mere kompliceret er derimod det specifikke anvendelsesområde, som i det følgende skal behandles indgående, idet de tre specifikationsgrader behandles enkeltvist.

\subsection{Det specifikke anvendelsesområde}

\subsubsection{Laveste specifikationsgrad - deiktisk kraft}

Med udgangspunkt i det empiriske materiale skal jeg i det følgende argumentere for, at ssf. er obligatorisk i underkategorien laveste specifikationsgrad, der er defineret ved specifikationsfaktoren deiktisk kraft. At deiktisk kraft medfører obligatorisk brug af ssf., står i direkte modstrid med antagelsen i Hartmann (1980). Dette grunder i, at jeg delvist anlægger et andet perspektiv på dette begreb end Hartmann (1980). Følgende eksempler skal illustrere dette:

(10) [i]ch sah mich da liegen, in Bochum auf dieser Vereinsbühne, besoffen, mit aufgeschürftem Knie, hörte im Saal das mitleidige Raunen und kam mir gemein vor

'jeg så mig selv ligge der, i Bochum på denne teaterforeningsscene, fuld,

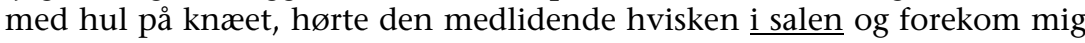
gemen'

(11) [B]evor wir auf ihr Zimmer gingen, blieben wir im Flur noch am Fenster stehen $[\ldots]$

'før vi gik op på hendes værelse, blev vi stående lidt ved vinduet $\underline{\text { i entréen' }}$

(12) [I]ch rief in die offene Küchentür hinein: "für mich kein Frühstück, Anna", ging rasch weiter und blieb im Wohnzimmer stehen

'jeg råbte gennem den åbne køkkendør: "Ingen morgenmad til mig, Anna", gik hurtigt videre og blev stående $\underline{\underline{i} \text { stuen' }}$

Mens Hartmann (1980) ville forklare brugen af ssf. i disse eksempler som følge af ikke-forisk kraft, finder jeg det mere hensigtsmæssigt at betragte (10), (11) og 


\section{MADS CHRISTIANSEN}

(12) som eksempler på deiktisk kraft, idet jeg ved dette begreb forstår det, at et givet objekt ud fra tekstinterne faktorer lader sig identificere. Her foreligger således ikke - som ved anaforisk og kataforisk kraft - henvisning til konkrete størrelser i den tekstuelle overflade, men identificerbarheden beror derimod på selve teksten som en "ramme", en "situation" eller "scene", som alene muliggør identificerbarhed. Dette lader sig konkretisere med udgangspunkt i (10). I dette eksempel lader Saal sig udelukkende identificere inden for den tekstskabte ramme, fortrinsvist på baggrund af tilstedeværelsen af ordet Vereinsbühne, der så at sige konstituerer "rammen", "situationen" eller "scenen" og således muliggør identificerbarheden af Saal.

Således foreligger også i (11) og (12) deiktisk kraft, idet man ud fra den tekstskabte ramme kan identificere Flur (11) og Wohnzimmer (12) som hørende til de omtalte rum eller boliger. Derved udelukkes, at der foreligger generisk anvendelse. $^{18}$

Sammenfattende kan om laveste specifikationsgrad siges, at man på baggrund af disse overvejelser vedrørende begrebet deiktisk kraft kan forklare størstedelen af de $\mathrm{i}$ det specifikke anvendelsesområde forekommende ssf. Ud over det hensigtsmæssige i ikke blot at definere disse ex negativo, som det er tilfældet hos Hartmann (1980), er det, at deiktisk kraft er forbundet med en lavere specifikationsgrad end anaforisk og kataforisk kraft helt $i$ den skalare beskrivelsesmodels logik. Referenceentydigheden er netop mindre i eksempler med deiktisk kraft end i de to andre specifikationsgrader, idet der som tidligere nævnt ikke henvises til konkrete tekstuelle størrelser. At ssf. er obligatorisk i laveste specifikationsgrad i modsætning til i de to andre specifikationsgrader, er derfor forståeligt.

Samlet må dette betragtes som et væsentligt led i forsøget på at beskrive det specifikke anvendelsesområdes dobbelte paradigme. I det følgende skal vi bevæge os et trin op ad den skalare beskrivelsesmodel og behandle underkategorien mellemste specifikationsgrad.

\subsubsection{Mellemste specifikationsgrad - variationsmulighedens domæne}

Mens ssf. er obligatorisk i laveste specifikationsgrad, åbner underkategorien mellemste specifikationsgrad undertiden op for en variationsmulighed mellem 
ssf. og apaf. Underkategorien består af to grupper: én med attribut som specifikationsfaktor bestående af tre typer med henholdsvis adjektivisk (type I), præpositionelt (type II) og genitivisk attribut (type III) og én med anaforisk kraft som specifikationsfaktor. De behandles i nævnte rækkefølge.

"Type I: Adj." og "Type II: Præp." opviser i modsætning til "Type III: Gen." stort set ingen variationsmulighed. Således optræder ssf. kun én gang i "Type I: Adj.":

(13) [e]ine Frau im rostroten Morgenmantel auf der schwarzen Couch hätte gut gepaßt $[\ldots]^{19}$

'en kvinde $\underline{i}$ en rustrød morgenkåbe på den sorte sofa ville have passet godt'

mens der i alle øvrige eksempler af denne type forekommer apaf., fx:

(14) [s]ogar in dem verhältnismäßig trockenen Kartoffelkeller lagen Bücher [...] 'sågar i den forholdsvist tørre kartoffelkælder lå der bøger'

Ifølge Nübling (2005: 111), der som en af de få i forskningen til emnet kort behandler attributive adjektivers betydning for valget mellem ssf. og apaf., er ssf. i eksempler med attributivt adjektiv uden videre mulig. Det empiriske materiale må således siges ikke helt at svare til dette billede. Nogen endelig konklusion angående brugen af ssf./apaf. ved attributivt adjektiv kan på grundlag af det empiriske materiale dog ikke drages.

I "Type II: Præp." forekommer kun apaf., fx:

(15) [d]er sitzt [...] in dem Bumslokal an der Ecke und fragt die Leute nach Achim 'han sidder på det snuskede værtshus på hjørnet og spørger folk om Achim'

"Type I: Adj." og "Type II: Præp." skal behandles nærmere under behandlingen af højeste specifikationsgrad med henblik på deres interaktion med "Type I: Anaf. + adj." og "Type II: Anaf. + præp." i denne underkategori. En nærmere forklaring heraf følger i den forbindelse.

I "Type III: Gen." består en variationsmulighed mellem ssf. og apaf.: 


\section{MADS CHRISTIANSEN}

(16) $[$ E]r bezeichnete sich [...] immer als ungelernter Arbeiter im Weinberg des Herrn [...]

'han betegnede sig altid som ufaglært arbejder i Herrens vingård'

(17) [s]ie suchte in dem Gesicht des Kunden [...]

'hun søgte i kundens ansigt'

Skønt ssf. er hyppigst forekommende i denne type, synes valget mellem ssf. og apaf. i overvejende grad frit. Væsentligt er dog at understrege, at dette valg altid er forbundet med en semantisk nuanceforskel, jf. det, at im er et specielt klitikon. Sammenligner man (16) og (17), kan man argumentere for, at Gesicht pga. apaf. betones eller fremhæves mere end Weinberg med ssf. Af denne grund er eksempler med apaf. af denne type placeret længere mod højre i den skalare beskrivelsesmodel end eksempler med ssf. Således synes påstanden i Nübling (2005: 110) om, at ssf. er obligatorisk ved genitivisk attribut, at måtte revideres. Begge muligheder synes, med den omtalte semantiske nuanceforskel, at foreligge. Dog må man holde sig for øje, at det også her ville forudsætte inddragelse af et større eksempelmateriale at drage en endelig konklusion herom.

Også i mellemste specifikationsgrads anden gruppe foreligger undertiden en variationsmulighed mellem ssf. og apaf. Dette er overraskende, idet en grundantagelse $\mathrm{i}$ forskningen er, at apaf. er obligatorisk i eksempler med anaforisk kraft. ${ }^{20}$ Betragter man:

(18) [I]ch blieb auf der Freitreppe stehen und vergewisserte mich meiner Schlüssel: zur Haustür, zur Wohnungstür, zum Schreibtisch; im Schreibtisch würde ich finden: die Fahrradschlüssel

'Jeg blev stående på den udvendige trappe og forvissede mig om, at jeg havde mine nøgler: til gadedøren, til døren ind til lejligheden, til

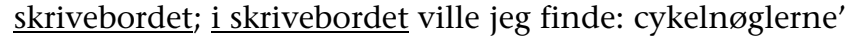

ses ssf. i et eksempel med anaforisk kraft: Schreibtisch, der just er blevet nævnt, er entydigt tilbagevisende. Således synes en grundantagelse i forskningen at måtte revideres.

Da det næppe forholder sig således, at den konstaterede variationsmulighed altid foreligger, må det naturligvis søges forklaret, hvornår dette er tilfældet. Ud fra 
den skalare beskrivelsesmodels fastafgrænsede trin kan man imidlertid ikke afgøre, hvornår ssf. i eksempler med anaforisk kraft er mulig. Blot kan man konstatere, at variationsmuligheden undertiden foreligger. Der opstår således et metodisk problem, idet der må stilles spørgsmålstegn ved det hensigtsmæssige i ved skalar at forstå fastafgrænsede trin. Man kan overveje, om det ville være mere frugtbart ved skalar at forstå et kontinuum med glidende overgange mellem de forskellige trin. Et sådant kontinuum kunne nemlig tage højde for flere kontekstuelle faktorer, end der er indbefattet i de fastlagte definitioner på de respektive specifikationsgrader. Da det af hensyn til den samlede vurdering af den skalare beskrivelsesmodel anses for vigtigt at få dette afklaret, skal i det følgende undersøges, om den konstaterede variationsmulighed kan forklares ud fra andre kontekstuelle faktorer end de $\mathrm{i}$ definitionen på de enkelte specifikationsgrader indbefattede. Det understreges, at der ikke er tale om en fuldstændig beskrivelse ud fra dette perspektiv, man at det blot har karakter af overvejelser, der udelukkende tjener det formål at afgøre, om en sådan tilgangsvinkel ville være mere hensigtsmæssig.

Der skal anføres to faktorer, der ikke er indbefattet i definitionen på de respektive specifikationsgrader, som synes at muliggøre ssf. i eksempler med anaforisk kraft. Dels synes dette muligt, når den størrelse, der vises tilbage til, er indført i teksten med ssf. eller tidligere i teksten er blevet nævnt med ssf. Dette gør sig bl.a. gældende i (18). Dels synes dette muligt, når den størrelse, der vises tilbage til, er indført i teksten med den ubestemte artikel. Dette gør sig gældende i flere af de undersøgte eksempler. Det understreges, at disse faktorer blot synes at muliggøre ssf. Således optræder i sådanne eksempler undertiden også apaf.

Det kan imidlertid konkluderes, at inddragelsen af flere kontekstuelle faktorer åbner muligheden for en mere detaljeret beskrivelse af den konstaterede variationsmulighed. Dette skal her ikke behandles yderligere, men senere gøres til genstand for diskussion $i$ den endelige vurdering af den skalare beskrivelsesmodel.

Man skal dog holde sig for øje, at der i de fleste eksempler med anaforisk kraft som specifikationsfaktor anvendes apaf. som i følgende eksempler: 


\section{MADS CHRISTIANSEN}

(19) [I]ch ging [...] ins Zimmer zurück und wählte [...] die Nummer des Dings, in dem Leo studiert [...] Es dauerte lange, ehe sich in dem Ding jemand bequemte, ans Telefon zu kommen [...]

'jeg gik tilbage på værelset og valgte nummeret på den tingest, som Leo

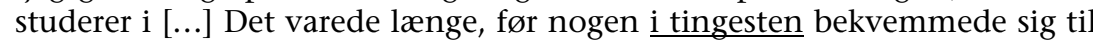
at komme til telefonen'

(20) [S]o wußte ich auch, wie lange Greff für sein Loch in der Eisdecke brauchte [...] Uralt und grau [...] stand das Wasser in dem Loch

'således vidste jeg også, hvor længe Greff behøvede til sit hul i islaget [...] Ældgammelt og gråt stod vandet $\underline{\text { i hullet' }}$

hvor Ding og Loch, som det fremgår, tidligere er blevet nævnt. Dette er hovedreglen.

Sammenfattende kan til underkategorien mellemste specifikationsgrad siges, at når der her - i modsætning til de to andre specifikationsgrader - undertiden foreligger en variationsmulighed, så må det være, fordi specifikationsfaktorerne i denne underkategori på den ene side besidder større referenceentydighed end deiktisk kraft, hvor ssf. er obligatorisk, på den anden side mindre referenceentydighed end kombinationen af to specifikationsfaktorer eller kataforisk kraft, hvor apaf., som vi skal se, er obligatorisk. ${ }^{21}$ Skønt den skalare beskrivelsesmodel ikke kan beskrive, hvornår denne variationsmulighed præcist foreligger, er det dog ikke uvæsentligt, at man på baggrund af den skalare beskrivelsesmodel kan fastlægge variationsmulighedens domæne til underkategorien mellemste specifikationsgrad.

I det følgende skal undersøges, hvilke forhold der gør sig gældende i højeste specifikationsgrad.

\subsubsection{Højeste specifikationsgrad - obligatorisk brug af apaf.}

I modsætning til mellemste specifikationsgrad opviser højeste specifikationsgrad, der er defineret ved kombination af mindst to specifikationsfaktorer eller kataforisk kraft, ingen variationsmulighed mellem ssf. og apaf. Apaf. er obligatorisk. Underkategorien består af fire typer. Type I er karakteriseret ved kombinationen "anaforisk kraft + attributivt adjektiv" (21), type II ved "anaforisk kraft + præpositionelt attribut" (22), type III ved andre kombinationer af specifikationsfaktorer, bl.a. "attributivt adjektiv + præpositionelt attribut", 
"anaforisk kraft + genitivisk attribut", og type IV ved kataforisk kraft (25), (26) og (27).

Mht. "Type III: Andre komb." skal nævnes, at en udtømmende beskrivelse af de herhenhørende eksempler naturligvis ville forudsætte en fordeling af disse på flere typer afhængig af den respektive kombination af specifikationsfaktorer. Da det empiriske materiale opviser forholdsvist få eksempler på de forskellige kombinationer indeholdt i "Type III: Andre komb.", samles de i én type. Eksemplerne i denne type svarer til det billede, der ses i "Type I: Anaf. + adj." og "Type II: Anaf. + præp.", hvorfor de ikke behandles nærmere.

"Type I: Anaf. + adj." og "Type II: Anaf. + præp." skal behandles med henblik på deres interaktion med "Type I: Adj." og "Type II: Præp." i mellemste specifikationsgrad. Herved forstås, at disse typer parvist, (21) og (23), (22) og (24), pga. den fælles specifikationsfaktor adjektivisk eller præpositionelt attribut ved første øjekast minder om hinanden, men ved nærmere eftersyn adskiller sig fra hinanden, idet kun eksemplerne i højeste specifikationsgrad derudover har specifikationsfaktoren anaforisk kraft.

Sammenligner man følgende eksempler fra højeste specifikationsgrads "Type I: Anaf. + adj." og "Type II: Anaf. + præp.":

(21) [E]s lag soviel Zärtlichkeit in dem winzigen Wort, da $\beta$ ich dachte [...] 'der lå så megen ømhed i det lille bitte ord, at jeg tænkte'

(22) [w]enn Sie mir sagen, daß diese Geheimkonferenzen in dem Hotel in Hannover [...] dem Zweck dienten [...]

'hvis De fortæller mig, at disse hemmelige konferencer $\underline{\mathrm{i} \text { hotellet } \mathrm{i}}$ Hannover tjente det formål'

med følgende eksempler fra mellemste specifikationsgrads "Type I: Adj." og "Type II: Præp.":

(23) [S]ie hatte inzwischen Rauchen gelernt, in dem lindgrünen Pullover sah sie schön aus [...]

'hun havde i mellemtiden lært at ryge, i den lindegrønne sweater så hun smuk ud' 


\section{MADS CHRISTIANSEN}

(24) [d]as Mädchen, das in dem Einfamilienhaus an der Ecke wohnte 'pigen, som boede i villaen på hjørnet'

træder en forskel frem på det semantiske niveau. Mens (21) og (22) fremstår som entydigt identificerbare, idet man under inddragelse af konteksten præcis ved, hvad der henvises til, er dette i (23) og (24) ikke tilfældet. Her er kommunikationen tekstintern, idet læseren - i modsætning til producenten af den sproglige sekvens - ikke er i stand til at identificere de omtalte størrelser.

Denne semantiske forskel kan siges at grunde i eksemplernes forskellige antal af specifikationsfaktorer. Begrebet specifikationsgrad er således ikke blot et rent mekanisk begreb, der udelukkende kan benyttes til at sige noget om valget mellem ssf. og apaf., men retfærdiggøres også på det semantiske niveau.

"Type IV: Kataf." adskiller sig fra underkategoriens tre andre typer ved ikke på baggrund af kombination af mindst to specifikationsfaktorer, men på baggrund af kataforisk kraft at høre til højeste specifikationsgrad. Det skal understreges, at det udelukkende er spørgsmålet om kataforisk kraft, der er blevet lagt til grund for indordningen af eksempler i denne type. Nogle af disse eksempler opviser således også flere andre specifikationsfaktorer end kataforisk kraft. For overskuelighedens skyld behandles de dog samlet i én type, jf. "Type III: Andre komb.".

Der hersker i forskningen konsensus om, at apaf. i eksempler som:

(25) $[u]$ nd sah mir selbst während des Essens in dem Spiegel zu, der über dem Eisschrank hängt

'og betragtede under måltidet mig selv i spejlet, der hænger over køleskabet'

(26) [R]ate mal, was in dem Sack ist, den der Musiker Meyn in den Müllkasten gesteckt hat

'gæt engang, hvad der er $\underline{\mathrm{i} \text { den sæk, som musikeren Meyn har puttet } \mathrm{i}}$ $\underline{\text { skraldespanden' }}$

hvor den kataforiske kraft grunder i, at Spiegel og Sack efterfølgende bestemmes nærmere af en relativsætning, er obligatorisk. ${ }^{22}$ Bl.a. Nübling (1992: 171f) har dog gjort opmærksom på, at parentetiske relativsætninger kan åbne muligheden 
for brug af ssf. Da det empiriske materiale ikke opviser eksempler herpå, skal dette ikke behandles yderligere.

Det empiriske materiale taler for også at lade "Type IV: Kataf." omfatte eksempler, hvis kataforiske kraft grunder i andre arter af efterfølgende bisætninger end relativsætninger. Det drejer sig bl.a. om dass-sætninger:

(27) [A]uch suchte und fand ich teilweise einen Sinn in dem Umstand, daß hier [...] die beiden Skatbrüder [...] liegen sollten

'jeg søgte og fandt også delvist en mening i den omstændighed, at de to skatbrødre skulle ligge her'

Dette synes i forskningen som oftest at blive overset. ${ }^{23}$

At eksempler med kataforisk kraft hører til i højeste specifikationsgrad, er vanskeligt at forklare med udgangspunkt i (25) og (26). Mens forskellen mellem deiktisk kraft, hvor der ikke henvises til konkrete størrelser i den tekstuelle overflade, og anaforisk og kataforisk kraft, hvor dette derimod er tilfældet, synes nogenlunde klar, er det ud fra disse eksempler vanskeligere at forklare, hvorfor kataforisk kraft skulle besidde større referenceentydighed end anaforisk kraft og dermed opvise obligatorisk brug af apaf. Med (27) synes det dog til dels at forholde sig anderledes, da det i sig selv nærmest indholdstomme substantiv Umstand specificeres semantisk gennem dass-sætningen, hvorved den referentielle entydighed her er meget udtalt. $^{24}$

Sammenfattende kan om eksemplerne i højeste specifikationsgrad (type I-III) siges, at de taler for det hensigtsmæssige i også at lade begrebet specifikationsgrad afhænge af antallet af specifikationsfaktorer. Derved bliver det tydeligt, at brugen af apaf. ikke lader sig udtømmende beskrive alene på baggrund af spørgsmålet om forisk kraft, som det fx er forsøgt hos Hartmann (1980), for som vi så, åbner anaforisk kraft op for muligheden for ssf., når den er den eneste specifikationsfaktor. Når den anaforiske kraft derimod kombineres med endnu en specifikationsfaktor, er kun apaf. mulig. Forklaringen må være, at kombination af flere specifikationsfaktorer medfører større referenceentydighed.

Før end der drages endelige konklusioner om den skalare beskrivelsesmodel, skal to særtilfælde, der ikke omfattes heraf, kort behandles. 


\section{MADS CHRISTIANSEN}

\subsection{To særtilfælde: Unika og idiomatiske udtryk}

Eksempler med henvisning til unika, dvs. objekter, af hvilke der kun findes ét eksemplar, omfattes ikke af den skalare beskrivelsesmodel, da spørgsmålet om, hvorvidt der henvises til en klasse af objekter eller til ét enkelt objekt her er meningsløst, idet den respektive klasse kun består af ét objekt. Et eksempel herpå er:

(28) [s]ie besteht aus mehr als sechshundert Abläufen, deren Choreographie ich [...] im Kopf haben muß $[\ldots]^{25}$

'det består af mere end sekshundrede forløb, hvis koreografi jeg skal have i $\underline{\text { hovedet' }}$

Heller ikke idiomatiske udtryk skal forsøges indplaceret $\mathrm{i}$ den skalare beskrivelsesmodel, da dette pga. denne gruppes særlige karakter anses for uhensigtsmæssigt. Ikke blot egentlige idiomatiske udtryk, men også faste vendinger og faste ordforbindelser medregnes til denne gruppe. Et eksempel herpå er:

\section{(29) [d]em steht nichts im Wege [...]}

'det er der ikke noget i vejen for'

At disse to særtilfælde ikke indplaceres i den skalare beskrivelsesmodel, betragtes ikke som et metodisk problem, idet de er ganske uproblematiske, da ssf. i begge tilfælde er obligatorisk. For overblikkets skyld er de i bilaget placeret i en oversigt under den skalare beskrivelsesmodel. I den endelige vurdering af den skalare beskrivelsesmodel i næste kapitel ses bort fra disse grupper.

\section{VURDERING AF DEN SKALARE BESKRIVELSESMODEL}

Afsluttende skal drages den endelige konklusion om den skalare beskrivelsesmodels anvendelighed. Særligt ét kritikpunkt skal i den forbindelse behandles.

Som nævnt i forrige kapitel udgør mellemste specifikationsgrads anden gruppe, eksempler med specifikationsfaktoren anaforisk kraft, et metodisk problem, idet man ud fra den skalare beskrivelsesmodel ikke kan forklare, hvornår ssf. her er mulig. Med andre ord kan man ikke beskrive de sproglige realiteter helt 
fyldestgørende med udgangspunkt i fastafgrænsede trin i en skalar model. Det er imidlertid vigtigt at pointere, at den skalare beskrivelsesmodel generelt betragtet udmærker sig ved at kombinere systematik med hensyntagen til fænomenets kompleksitet. Således er beskrivelsen af det specifikke anvendelsesområdes dobbelte paradigme ud fra begrebet specifikationsgrad mere detaljeret end de fleste andre af forskningens forklaringsforsøg.

Beskrivelsesmæssige vanskeligheder er at forvente ved enhver beskæftigelse med emnet, da det ikke er helt regelstyret. Da det af hensyn til den skalare beskrivelsesmodels praktiske anvendelighed anses for fornuftigt at operere med fastafgrænsede trin, betragtes det som uhensigtsmæssigt at inddrage andre kontekstuelle faktorer i beskrivelsen, skønt dette som tidligere vist kunne give en mere nuanceret beskrivelse af det omtalte problem. Generelt må den skalare beskrivelsesmodel med den anlagte systematik siges at give en præcis beskrivelse af fænomenet.

Forudsætningen for den skalare beskrivelsesmodels netop omtalte evne til via systematik præcist at beskrive fænomenet er - ud over korrelationen af Hartmann (1978) og Hartmann (1980) - revurderinger af antagelser, der tidligere i forskningen blev anset for fakta. Konkret har jeg vist, at forisk kraft står i et mere komplekst forhold til valget mellem ssf. og apaf. end hidtil antaget. Således fordeler deiktisk, anaforisk og kataforisk kraft sig på det specifikke anvendelsesområdes tre specifikationsgrader. Herved gøres op med den i forskningen udbredte antagelse, at forisk kraft - typen underordnet - altid medfører apaf.

Endvidere blev vist, at også attributter, hvis betydning i forskningen hidtil har været undervurderet, har betydning for valget mellem ssf. og apaf. Det empiriske materiales eksempler med attribut som eneste specifikationsfaktor er dog som antydet for lille til, at endelige konklusioner angående disses betydning kan drages. En problemspecifik undersøgelse ville i denne forbindelse være hensigtsmæssig.

Grundlæggende må den opstillede tese således siges at være blevet understøttet. Forskellen i brug af ssf. og apaf. kan beskrives ud fra en skalar beskrivelsesmodel byggende på spørgsmålet om referenceegenskaber. 


\section{MADS CHRISTIANSEN}

Man skal mht. den skalare beskrivelsesmodel være opmærksom på, at mine undersøgelsesresultater må formodes kun at gælde for de seks mest grammatikaliserede ssf. Hvorvidt den skalare beskrivelsesmodel lader sig applicere på de enkle klitika, er uvist. Under alle omstændigheder ville et forsøg herpå stille krav om en forfining af beskrivelsesmodellen, da en udelukkelse af det fonetiske aspekt og grammatikaliseringsaspektet her ikke er mulig. Hvorledes dette i praksis kan gennemføres, skal ikke diskuteres her, dog må en grundmodel til brug i en sådan undersøgelse antages at være blevet leveret i form af den opstillede skalare beskrivelsesmodel.

\section{LITTERATUR}

\section{Tekster fra Mannheimer Korpus 1}

Bergengrün, Werner (1950), Das Tempelchen, Zürich: Arche (lbt).

Böll, Heinrich (1963), Ansichten eines Clowns, Köln/Berlin: Kiepenheuer \& Witsch (lbc).

Frisch, Max (1965), Homo Faber, Frankfurt am Main: Suhrkamp (lfh).

Grass, Günter (1964), Die Blechtrommel, Frankfurt am Main: Fischer (lgb).

Johnson, Uwe (1961), Das dritte Buch über Achim, Frankfurt am Main: Suhrkamp (lja).

Mann, Thomas (1953), Die Betrogene, Frankfurt am Main: Fischer (lmb).

Strittmatter, Erwin (1963), Ole Bienkopp, Berlin: Aufbau (lso).

\section{Sekundærlitteratur}

Bisle-Müller, Hansjörg (1991), Artikelwörter im Deutschen. Semantische und pragmatische Aspekte ihrer Verwendung, Tübingen: Niemeyer.

Behaghel, Otto (1923), Deutsche Syntax, Bd. II, Heidelberg: Winters.

Consten, Manfred (2004), Anaphorisch oder deiktisch? Zu einem integrativen Modell domänengebundener Referenz, Tübingen: Niemeyer.

Duden 4 (1998) = Duden - Grammatik der deutschen Gegenwartssprache, 6 . Auflage, Mannheim, Leipzig, Wien, Zürich: Dudenverlag.

Eisenberg, Peter (1999), Grundriß der deutschen Grammatik, Bd. II, Der Satz, Stuttgart/Weimar: Metzler.

Engel, Ulrich (2004), Deutsche Grammatik, Neubearbeitung, München: Iudicium.

Haberland, Hartmut (1985), "Zum Problem der Verschmelzung von Präposition und bestimmtem Artikel im Deutschen", Osnabrücker Beiträge zur Sprachtheorie, 30 (1985), pp. 82-106.

Hartmann, Dietrich (1978), "Verschmelzungen als Varianten des bestimmten Artikels?", in: Hartmann, Dietrich, Hansjürgen Linke, Otto Ludwig (Hgg.) 
(1978), Sprache in Gegenwart und Geschichte. Festschrift für Heinrich Matthias Heinrichs zum 65. Geburtstag, Köln/Wien: Böhlau, pp. 68-81.

Hartmann, Dietrich (1980), "Über Verschmelzungen von Präposition und bestimmtem Artikel", Zeitschrift für Dialektologie und Linguistik, 47 (1980), pp. 160-183.

Helbig, Gerhard, Joachim Buscha (1996), Deutsche Grammatik. Ein Handbuch für den Ausländerunterricht, 17. Auflage, Leipzig, Berlin, München: Langenscheidt.

Nübling, Damaris (1992), Klitika im Deutschen. Schriftsprache, Umgangssprache, alemannische Dialekte, Tübingen: Narr.

Nübling, Damaris (2005), "Von in die über in'n und ins bis im. Die Klitisierung von Präposition und Artikel als 'Grammatikalisierungsbaustelle'", in: Leuschner, Torsten, Tanja Mortelmans, Sarah De Groodt (Hgg.) (2005), Grammatikalisierung im Deutschen, Berlin/New York: de Gruyter, pp. 105-131.

Raffelsiefen, Renate (1987), "Verschmelzungsformen in German: A Lexical Analysis", Linguistic Analysis, 17 (1987), pp. 123-146.

Schaub, Sybille (1979), "Verschmelzungsformen von Präpositionen und Formen des bestimmten Artikels im Deutschen", in: Vater, Heinz (Hg.) (1979), Phonologische Probleme des Deutschen, Tübingen: Narr, pp. 63-104.

Schellinger, Wolfgang (1988), "Zu den Präposition-Artikel-Verschmelzungen im Deutschen", Linguistische Berichte, 115 (1988), pp. 214-228.

Schmöe, Friederike (2004), "Fahr zur Hölle! Über Verschmelzungen aus Präposition und bestimmtem Artikel und ihre Grammatikalisiertheit", Neuphilologische Mitteilungen, 105 (2004), pp. 209-230.

\section{NOTER}

1 Jeg skylder lektor Harald Pors tak for kommentarer til udkast af denne artikel.

2 Et tilsvarende billede ses eksempelvis i Helbig/Buscha (1996) og Engel (2004). Da nærværende artiklel har været undervejs i et par år, har det ikke været muligt at tage højde for nyere udgaver af Duden 4.

3 Se dog Nübling (1992: 171-174).

4 Også ældre behandlinger af emnet foreligger, fx Behaghel (1923). Disse skal imidlertid ikke behandles nærmere, da de vurderes ikke at have relevans for opstillingen af en skalar beskrivelsesmodel.

5 "Funktionel" anvendes i denne artikel i almensproglig forstand, dvs. at det indikerer en fokus på ssf. og apaf. som to modsætninger, hvis respektive bidrag eller funktion skal undersøges.

6 Der ses bort fra behandlinger af emnet under sætningsfonetisk perspektiv, fx Schaub (1979), idet sætningsfonetikken udelukkende anses for relevant for en beskrivelse af ssf./apaf. i det talte sprog.

7 Specielle og enkle klitika er min oversættelse af "spezielle Klitika" og "einfache Klitika".

8 Den umiddelbart noget upræcise betegnelse "god" bygger her, som hos Schmöe (2004), på prototypeteorien.

9 Eksempel fra Hartmann (1978: 70). 


\section{MADS ChRISTIANSEN}

10 For nærmere formelle kriterier for de to interpretationer se Hartmann (1978: 70-73). Her findes også eksempler på mulige anvendelser af den ubestemte artikel, der ud over generisk og specifik anvendelse også opviser såkaldt uspecifik anvendelse. Dette skal dog ikke behandles nærmere i denne artikel, der som udgangspunkt beskæftiger sig med den bestemte artikel.

11 Se fx Nübling (1992) og Schmöe (2004).

12 Eksempel fra Duden 4 (1998: 327).

13 Dette og det følgende eksempel er begge fra Hartmann (1980: 176).

14 Begrebet anaforisk kraft skal ikke problematiseres yderligere. For en af de nyeste behandlinger af anaforisk kraft - og andre af den foriske krafts underbegreber - se Consten (2004).

15 Det er vanskeligt at opstille klare kriterier for målbarhed af referenceentydighed. De her gjorte overvejelser tjener således primært det formål at bidrage til opstilling af en beskrivelsesmodel relevant i denne undersøgelse, men bør ikke betragtes som en generel teori.

16 Eksempel fra Duden 4 (1998: 258).

17 Således regner Schmöe (2004: 216), idet hun baserer sig på Eisenberg (1999), "am Vormittag" for generisk. Dette eksempel må siges at ligge tæt op ad (6) og (7). Alligevel lader det sig diskutere, hvorvidt (6) og (7) bør betragtes som eksempler på generisk anvendelse, idet de nok snarere udtrykker noget habituelt. Da habituel anvendelse imidlertid perifert synes at kunne indordnes under generisk anvendelse, behandles de $i$ denne artikel som sådan. For en indgående behandling af generisk anvendelse af artikelordene i tysk se Bisle-Müller (1991: 133-155).

18 I enkelte eksempler kan den deiktiske kraft dog også siges at grunde i tilstedeværelsen af et stedsadverbium, pga. hvilket det respektive objekt lader sig identificere. Dette stiller dog ikke spørgsmålstegn ved det formålstjenlige i min brug af begrebet, der adskiller sig fra den hos Hartmann (1980) ved ikke blot at fokusere på kommunikationssituationen i snæver forstand, men i højere grad på selve teksten som den "ramme", der sikrer identificerbarhed.

19 Eksemplet illustrerer et andet aspekt ved fænomenet. Således synes her den ubestemte artikel at være i spil, hvilket dog ikke forekommer med tilnærmelsesvist samme hyppighed som sammensmeltning med den bestemte artikel, som denne artikel primært beskæftiger sig med.

20 Se, ud over Hartmann (1980), fx Raffelsiefen (1987) og Schellinger (1988).

21 Det interne forhold mellem specifikationsfaktorerne attribut og forisk kraft skal ikke behandles nærmere, da det ud fra grammatiske principper er vanskeligt at sige noget herom.

22 Se fx Hartmann (1978) og Nübling (2005).

23 Se fx behandlingen af kataforisk kraft hos Raffelsiefen (1987), Schellinger (1988) og Nübling (2005), der alle tre kun behandler relativsætninger.

24 Mht. eksemplerne med kataforisk kraft bør også nævnes, at der her i stedet for bestemt artikel undertiden foreligger demonstrativpronomen. Da det i skriftsproget er vanskeligt at skelne det adjektivisk brugte demonstrativpronomen fra den bestemte artikel, behandles demonstrativpronomen, ved hvilket apaf. er obligatorisk, generelt ikke nærmere.

25 Min forståelse af begrebet lægger sig op ad den udvidede definition hos Schellinger (1988: 217f), der også omfatter eksempler med henvisning til objekter, der udelukkende ud fra den kontekst, de anvendes i, er at betragte som unika. Dette er tilfældet i (28), hvor Kopf i denne kontekst fremstår som et unikum, idet mennesket, her repræsenteret ved ordet ich, kun har ét hoved. Ved egentlige unika som fx "paven" 
IM ELLER IN DEM? ET FORS $\varnothing G$ PÅ EN SKALAR FORKLARING

spiller det kontekstuelle derimod ingen rolle. Da det empiriske materiale opviser flest eksempler på den første type unika, er (28) bragt som eksempel herpå. 


\section{MAds Christiansen}

\section{BILAG}

\section{Den skalare beskrivelsesmodel}

I den skalare beskrivelsesmodel er angivet frekvensen af ssf./apaf. i de respektive underkategorier. Endvidere er de i undersøgelsen bragte eksempler fra Mannheimer Korpus 1, nummereret 6-29, angivet med sigel og efterfølgende sidehenvisning.

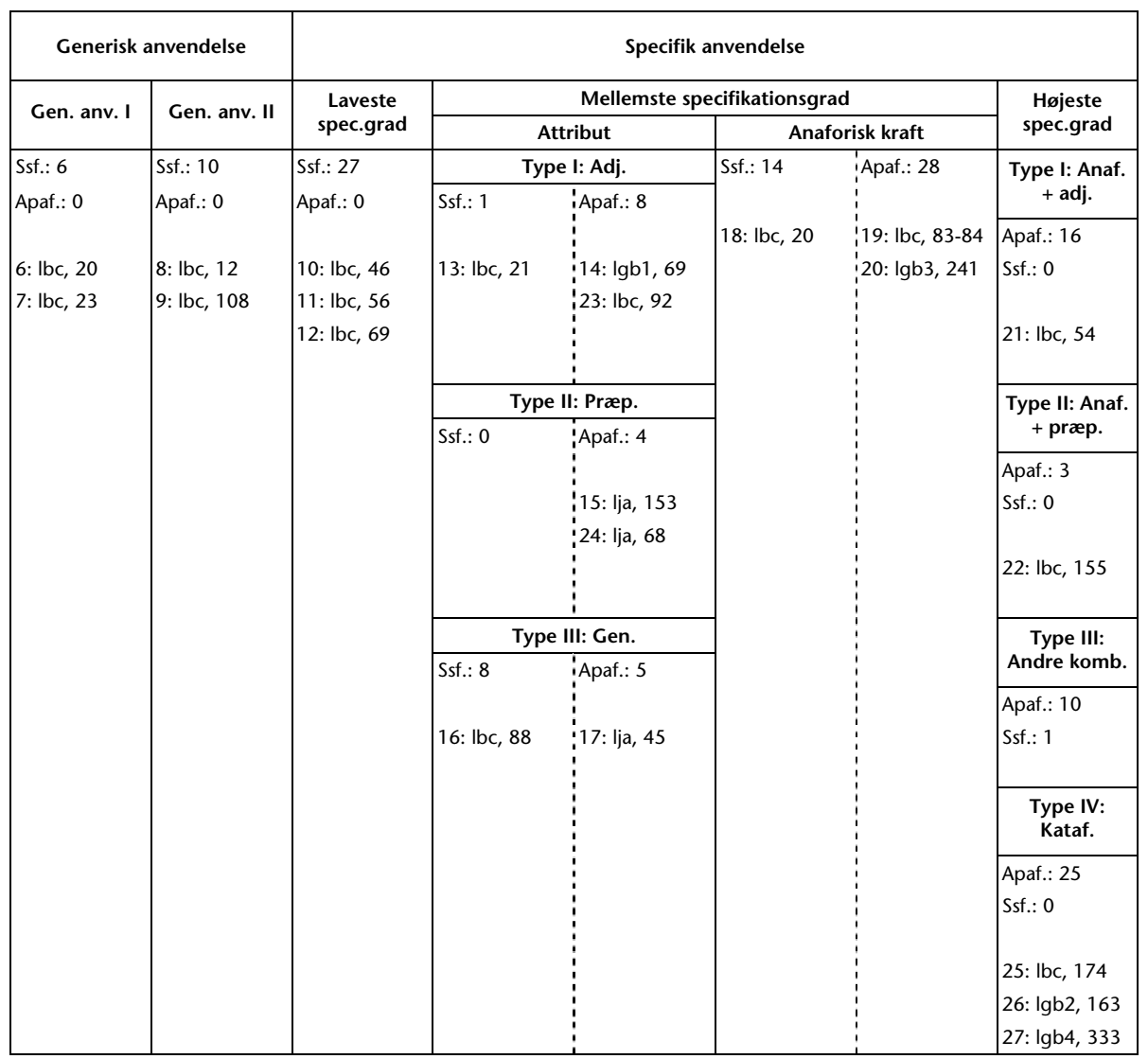

Særtilfælde

\begin{tabular}{|l|l|}
\hline \multicolumn{1}{|c|}{ Unika } & \multicolumn{1}{|c|}{$\begin{array}{c}\text { Idiomatiske } \\
\text { udtryk }\end{array}$} \\
\hline Ssf.: 20 & Ssf.: 13 \\
Apaf.: 1 & Apaf.: 0 \\
28: Ibc, 12 & 29: Ibc, 15 \\
\hline
\end{tabular}

